\title{
Több támadáspontú gyógyszerek: múlt, jelen és jövő
}

\author{
Mátyus Péter dr. ${ }^{1,2}$ \\ ${ }^{1}$ Semmelweis Egyetem, Egészségügyi Közszolgálati Kar, Digitális Egészségtudományi Intézet, Budapest \\ ${ }^{2}$ E-Group ICT Software Zrt., Budapest
}

\begin{abstract}
Az egy betegség - egy célpont - egy gyógyszer paradigma az 1960-as évektól egészen a 2000-es évekig a gyógyszerkutatás meghatározó koncepciója volt. A gyógyszer-innováció eredményességének megtorpanása, ső́t visszaesése, az egy támadáspontú megközelítés különösen multifaktoriális betegségek terápiájára való alkalmazhatóságának elvi korlátai azonban ráirányították a figyelmet az egy betegség - több célpont - egy gyógyszer több támadáspontú gyógyszer koncepciójára. Áttekintő közleményünkben a több támadáspontú gyógyszerek régi és új molekulatervezési stratégiáit és azok gyakorlati megvalósítását ismertetjük saját és mások példáin keresztül, melyek a több támadáspontú megközelítés különleges terápiás és diagnosztikai értékeit és előnyeit is illusztrálják. Végül rámutatunk arra, hogy a több támadáspontú koncepció új lehetőségeket is nyújtó teljes potenciálja rendszerszemléletư megközelítéssel, célszerüen kvantitatív rendszerfarmakológiával és adatelemzési, adatasszociációs (például mesterséges intelligenciát alkalmazó) módszerekkel bontakozhat ki. A rendszerfarmakológiai gyógyszer koncepciója új áttörést jelentő hatóanyagokhoz, kombinációs készítményekhez és gyógyszer-repozíciós készítményekhez is vezethet.
\end{abstract}

Orv Hetil. 2020; 161(14): 523-531.

Kulcsszavak: több támadáspontú gyógyszer, gyógyszertervezés, rendszerfarmakológia, gyógyszer-kombináció, rendszerfarmakológiai gyógyszer

\section{Multi-targeting drugs: past, present and future}

The one disease - one target - one drug paradigm was an almost dominant principle in drug discovery from the 1960s to the 2000s. The stagnation and even decline in the productivity of drug innovation around the turn of the millennium and beyond, the realization of limitations of the one-target approach, especially in the treatment of multifactorial diseases, have drawn attention considerably to the one disease - multiple target - one drug multi-targeting drug concept. In this review, we outline old and new molecular design strategies and their practical implementation with own and other examples that also demonstrate unique therapeutic and diagnostic values and benefits of the multitargeting approach. Finally, we point out that the full potential of the multi-targeting concept can emerge through data analytics and association methods (such as artificial intelligence) and system-based approach, preferably by linking it to quantitative systems pharmacology. This new systems pharmacology drug approach may also lead to novel breakthrough drugs, drug combinations and drug repositioning.

Keywords: multi-targeting drug, drug design, systems pharmacology, drug combination, systems pharmacology drug

Mátyus P. [Multi-targeting drugs: past, present and future]. Orv Hetil. 2020; 161(14): 523-531.

(Beérkezett: 2019. december 9.; elfogadva: 2019. december 27.)

\footnotetext{
*A Szerkesztőség felkérésére készített tanulmány, amely a Szerzőnek a Szabó Sándor (Irvine, CA) és Vécsei László (Szeged) professzorok által „Innovatív medicina 2 . Új gyógyszerjelölt molekulák és orvosi műszerek: magyar kutatók és feltalálók” címmel a Magyar Tudományos Akadémián 2019. május 10-én rendezett szimpóziumon elhangzott előadása alapján készült.
} 


\section{Rövidítések}

$\mathrm{AChE}=($ acetylcholinesterase $)$ acetilkolin-észteráz; ADMET $=$ (absorption, distribution, metabolism, excretion, toxicity) abszorpció, disztribúció, metabolizmus, exkréció, toxicitás AIDS $=$ (acquired immune deficiency syndrome) szerzett immunhiányos tünetegyüttes; $\mathrm{A} \beta=$ (amyloid-beta) béta-amiloid; $\mathrm{C}=$ célfehérjekötő hely; $\mathrm{COX}=$ (cyclooxygenase $)$ ciklooxigenáz; $\mathrm{DML}=($ designed multiple ligand $)$ tervezett több támadáspontú ligandum; $\mathrm{F}$ = farmakofór; GYKI = Gyógyszerkutató Intézet; HTS = (high-throughput screening) nagy teljesítőképességú szűrés; MAMUT = (metabolism-activated multitargeting) több támadáspontú hatás metabolikus aktiválással; MAO-B = monoamin-oxidáz- $\mathrm{B} ; \mathrm{MRI}=$ (magnetic resonance imaging) mágnesesrezonancia-képalkotás; MTDL = (multitarget-directed ligand) több támadáspontra irányított ligandum; NMDA $=(N$-methyl- $D$-aspartate $) N$-metil- $D$-aszparaginát; $\mathrm{PET}=($ positron-emission tomography $)$ pozitronemissziós tomográfia; SSAO = (semicarbazide-sensitive amine oxidase) szemikarbazid-szenzitív aminoxidáz; TRPAl = (transient receptor potential ankyrin 1) tranziens receptorpotenciál ankirin- 1 TRPVI $=($ transient receptor potential vanilloid 1$)$ tranziens receptorpotenciál vanilloid- 1 ; USA $=($ United States of America) Amerikai Egyesült Államok

Az egy betegség - egy (molekuláris) célpont-egy (szelektív) gyógyszer ('egy zár - egy kulcs') paradigma a gyógyszerkutatás egyik fontos pillérét képezi a múlt század 60-as éveitől. Racionális alapját két tétel képezi: i) a kívánt ('on-target') terápiás hatás elérhető a betegség patomechanizmusa egyetlen (kulcsszerepet játszó) elemének szelektív befolyásolásával, ii) az egy támadáspontú szelektivitásnak köszönhetően nem alakul ki nem kívánt ('off-target') mellékhatás (szemben a nem szelektív hatóanyagokkal, amelyek a célponton kívül a szervezet más helyeihez is kötődve, akár súlyos mellékhatásokat okozhatnak). Lényegében ennek a megközelítésnek az alapján és támogatására alakult ki az 1980-as években nagyszámú vegyület vizsgálatára alkalmas in vitro high-tech, robotizált HTS és in silico (virtuális, számítógépes) módszeregyüttes. Ez a nagy teljesítőképességű technológiai platform és az 1990-es évektől születő, nagy jelentőségű biomedicinális eredmények együtt alapozták meg és táplálták a gyógyszer-innováció minőségi és mennyiségi - jelentőségében szinte forradalminak vélt - megújításához füződő reményeket is.

Mindezek tükrében különösen meglepő, hogy a gyógyszerfejlesztési eredmények elmaradtak e reményektől. Az ezredfordulótól az évenként forgalomba kerülő új (kismolekulás) gyógyszerek száma - az elmúlt két év kiugróan magas számaitól eltekintve - alig változik vagy csökken (megemlítendő, hogy a biológiai készítmények száma viszont inkább emelkedő tendenciát mutat) [1]. Az innovációs sikerráta, vagy a másik oldalról kifejezve, az eredménytelen fejlesztések aránya hosszú ideje nem javul: a humán fázis I. vizsgálatokra kerülő hatóanyagok csupán $11,83 \%$-a, egy másik tanulmány szerint $13,8 \%$-a válik gyógyszerré $[2,3]$. Eközben egy új gyógyszer piacra kerülési költsége folyamatosan és rohamosan nő, napjainkban abszolút értékét tekintve is hatalmas költséget jelent ('out of pocket' költség: 1,395 millárd USD; kapitalizált költség: 2,558 millárd USD) [2], emellett viszont az egy gyógyszerre vetített, évenkénti forgalmi érték csökken vagy alig emelkedik [4]. Figyelemre méltó szintén, hogy számos komplex, köztük népegészségügyileg növekvő fontosságú (például neurodegeneratív) betegséget meggyógyítani vagy megelőzni képes gyógyszerek még ma sem állnak rendelkezésre. Az e tényekhez vezető okok feltárása nélkülözhetetlen lépés az eredményesebb gyógyszer-innováció érdekében. Számos kiváló tanulmány, elemezve különféle tényezők hatását, mutat rá a preklinikai szûrési módszereknek, a gyógyszerjelölt fizikai-kémai tulajdonságainak, sőt szervezési tényezőknek és az innovációs láncba integrált döntési mechanizmusnak és kritériumrendszerének a fontos szerepére $[5,6]$.

Nem kétséges azonban, hogy a gyógyszercélpont-pálasztás és a célpontok befolyásolásának módja, valamint gyógyszerkémiai realizálása különleges figyelmet érdemlő tényezők, az innovációs folyamat elején megjelenő és annak egészére döntően kiható szerepük miatt.

Áttekintő munkánkban a több támadáspontú gyógyszerekre fókuszálunk. Ismertetjük és elemezzük a koncepciót keletkezésétől jövőbeli szerepéig, összefoglalva a régi és új molekulatervezési stratégiákat és módszereket. E munka időszerüségét nem csupán az adja, hogy e hatóanyagtípus hozzájárulása a gyógyszerkincshez az utóbbi másfél évtizedben egyre növekszik $[7,8]$, hanem az is, hogy a koncepció jelenlegi rendszerszemléletű megújításával a jövő gyógyszer-innovációjának egyik hajtóerejévé válhat.

\section{A több támadáspontú gyógyszer koncepciójának kialakulása és fejlődése}

Az egy betegség - egy célpont - egy gyógyszer koncepció iránti töretlen bizalmat megingatta az a felismerés, hogy jó néhány, egy támadáspontú molekulaként fejlesztett gyógyszerról retrospektív analízisek kiderítették, hogy terápiás eredményességük több, akár sokkomponensű hatásmódjuknak köszönhető. Jól ismert példaként említhető az antipszichotikumok több generációja. Terápiás hatásukban egy tucat receptor is részt vehet. Másfelól az egy támadáspontú koncepció elvi korlátaira utalt a multifaktoriális (például neurodegeneratív, metabolikus, onkológiai) betegségek terápiájára fejlesztett, nagy szelektivitású gyógyszerjelöltek sorozatos eredménytelensége. Ez utóbbi tapasztalat a biológiai rendszer komplexitásával és kompenzációs képességével, valamint redundanciájával, azaz bizonyos inherens rendszertulajdonságokkal értelmezhető. Mindez a fejlemény különösen az ezredforduló tájékán irányította a figyelmet a több támadáspontú megközelítésre mint lehetséges gyógyszerhatás-koncepcióra.

A kettős támadáspontú, szimbiotikusnak is nevezett gyógyszerkoncepció azonban már az 1970-es években 
A

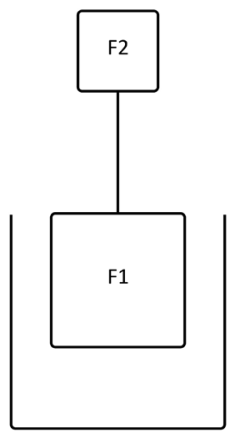

C1

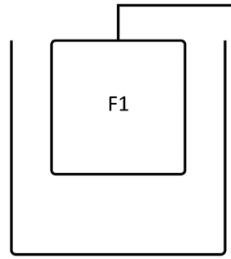

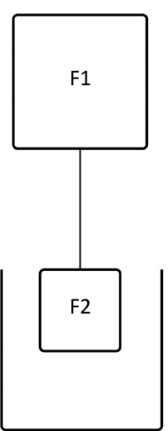

C2
B

1. ábra
Kettôs támadáspontú hatóanyag kapcsolódása a két célfehérjéhez. A kötődésben az F1 és F2 farmakofórok, illetve a Cl és C2 célfehérjekötő helyek vesznek részt. A két farmakofór $A$ esetben két független kötőhelyhez, míg $B$ esetben a két térbelileg közeli kötőhelyhez kapcsolódik

kialakult $[9,10]$. E szerint a kettős támadáspontú gyógyszermolekula a két célfehérjekötő hellyel (általában receptor- vagy enzimkötő hely) komplementáris farmakofórjai révén fejti ki farmakológiai hatását (a farmakofór a receptorkötődés feltételeit kielégítő szerkezeti tulajdonságok összességét jelenti). Az 1. ábrán szemléltetett re- ceptor-ligandum kölcsönhatási folyamatban a kettős támadáspontú gyógyszermolekula F1 és F2 farmakofórja kötődik a $\mathrm{C} 1$, illetve $\mathrm{C} 2$ célfehérjekötő helyekhez: a két farmakofór $A$ esetben két független kötőhelyhez, míg $B$ esetben a két térbelileg közeli kötőhelyhez kapcsolódik. Az 1977-ben forgalomba került labetalol (2. ábra) tekinthető az első szisztematikusan tervezett és fejlesztett, több támadáspontú gyógyszernek. Kettős, $\alpha_{1}{ }^{-}$ adrenoceptor- és $\beta$-receptor-blokkoló hatásának köszönhetően az akkoriban használt $\alpha$-adrenoceptorblokkolóknál előnyösebb vérnyomáscsökkentő szernek bizonyult [10]. Bár e sikeres gyógyszer alátámasztotta a koncepció értékét, az évekig csak szerény figyelmet kapott. Fokozódó érdeklődés az 1980-as, főként az 1990-es években tapasztalható, amit a projektek növekvő száma jól jelez, közülük egyébként több is gyógyszerhez vezetett. Ezek a példák (2. ábra) a megközelítés széles alkalmazhatóságát is illusztrálják: a szerotonin- és noradrenalin-újrafelvétel kettős gátlója a duloxetin antidepresszáns [11]; a duális kinázgátló lapatinib onkológiai gyógyszer [12]; míg a Richter Gedeon kariprazinkészítménye, finoman összehangolt $\mathrm{D}_{2}+\mathrm{D}_{3}$ dopaminreceptoriális hatáskomponenseinek köszönhetően [13], a szkizofrénia kezelésében egyedülállóan kedvező terápiás hatásspektrumú gyógyszer.

A több támadáspontú gyógyszerek innovációjának újabb, ma is tartó eredményes és példagazdag fejezete a 2000-es években indult. Első szakaszában, a kettős támadáspontú gyógyszer elvének általánosításával és korszerúsítésével, egységes értelmezést kapott a koncepció és a sokféle név is. Ennek értelmében a több támadáspontú hatóanyag/gyógyszer olyan célirányosan tervezett molekulát jelent, mely több molekuláris célponton át fejti ki<smiles>CC(CCc1ccccc1)NCC(O)c1ccc(O)c(C(N)=O)c1</smiles>

Labetalol<smiles>CN(C)C(=O)N[C@H]1CC[C@H](CCN2CCN(c3cccc(Cl)c3Cl)CC2)CC1</smiles>

Kariprazin<smiles>CS(=O)(=O)CCNCc1ccc(-c2ccc3ncnc(Nc4ccc(OCc5cccc(F)c5)c(Cl)c4)c3c2)o1</smiles><smiles>CNCC[C@H](Oc1cccc2ccccc12)c1cccs1</smiles>

Duloxetin

2. ábra $\quad$ Különféle terápiás célra alkalmazott kettős támadáspontú gyógyszerek. Labetalol: vérnyomáscsökkentő; duloxetin: antidepresszáns; lapatinib: az emlőrák bizonyos típusainak kezelésére; kariprazin: szkizofrénia kezelésére 
hatását, így több hatáskomponenssel rendelkezik. Különösen a tervezett több támadáspontú ligandum ('designed multiple ligand', DML) [14] és a több támadáspontra irányított ligandum ('multi-target-directed ligand', MTDL) [15] elnevezések terjedtek el. E hatóanyagtípus speciálisan komplex farmakológiai tulajdonságait a szelektív polifarmakológia ('selective non-selectivity') kifejezés fedi le, amellyel meg is különböztetjük őket a nem szelektív polifarmakológia ('non-selective non-selectivity') képviselőitől, az úgynevezett 'piszkos gyógyszerek'-től ('dirty drugs') [16]. Az utóbbiakat részletesen nem tárgyaljuk, csupán azt emeljük ki, hogy közöttük - a nem éppen kedvező megítélésükre utaló jelző ellenére - nagy sikerú gyógyszerek is vannak. Nem tervezett (rendszerint forgalomba kerülésük után tisztázott) összetett hatásmódjuk két vagy több szinergikus komponenssel értelmezhető; egyik jól ismert példájuk a sztatin gyógyszercsalád, amelynek koleszterinszintet csökkentő főhatását előnyösen egészíti attól független gyulladásgátló hatása.

A több támadáspontú koncepció sikertörténete ebben az évtizedben is folytatódott: gyógyszerjelöltek és gyógyszerek jelzik eredményességét [8, 17-23]. Mi a továbbiakban a koncepció tartalmi elemeire és gyógyszerkémiai realizálására koncentrálunk.

A gazdagodó tapasztalatok összegzésével jól azonosíthatók a több támadáspontú hatóanyagok terápiás előnyei: i) előnyös főhatás és/vagy ii) a mellékhatások kedvező spektruma. Másfelől, körvonalazhatók a több hatáskomponens egyetlen molekulában történő kifejezésének gyógyszerkémiai megoldásai.

\section{Több támadáspontú gyógyszerek és gyógyszer-kombinációk}

A több támadáspontú hatás elérésére nem az egyetlen elvi lehetőség a hatáskomponensek egy molekulába történő beépítése. A gyógyszerterápia régóta eredményesen alkalmaz ismert gyógyszerekkel képzett kombinációs készítményeket is. A két megoldás (egyetlen molekula esetén: 'polypharmacology', illetve kombináció esetén: 'polypharmacy' a nemzetközi szakirodalomban) közül a több támadáspont egy molekulába ötvözése általában előnyösebb. A kombinációs készítmény ugyanis eleve csak akkor jöhet számításba, ha rendelkezésre állnak megfelelő hatású, egy támadáspontú gyógyszerek. Amennyiben vannak is ilyenek, azok adott farmakokinetikájának és farmakodinámiájának össze- és finomhangolása azonban nem mindig lehetséges a dóziskorlátok vagy a komponensek közötti akár részleges vagy teljes inkompatibilitás miatt. Egy több támadáspontú molekula esetében ilyen korlátozó vagy kizáró szempontok nincsenek, továbbá a gyógyszer-rezisztencia kialakulásának veszélye is kisebb, valamint iparjogvédelmi szempontok érvényesítése is egyszerúbb (különösen, ha a tervezett kombináció gyógyszerkomponensei nem generikusak, és más-más tulajdonosaik vannak). Mindazonáltal a kombi- nációs készítmények továbbra is mérlegelésre érdemesek bizonyos betegségekben, így például az onkológiában vagy az AIDS terápiájában.

\section{Több támadáspontú hatóanyagok tervezése és előállítása}

Több hatáskomponens egyetlen molekulával történő kifejezésének többféle gyógyszerkémiai lehetőségét példákon keresztül ismertetjük.

\section{Több támadáspontú hatóanyagok farmakofórok összekapcsolásával}

Ez a megoldás két szakaszból áll: i) a farmakofórok meghatározása, ii) azoknak szintetikus kémiai módszerekkel történő megfelelő összekapcsolása. A farmakofórok azonosítása kellő számú farmakológiai adat vagy a kötôhelyek szerkezetének birtokában nem jelent különös nehézséget. Általában az egy támadáspontú ligandumok esetében bevált gyógyszerkémiai és/vagy ligandalapú vagy a kötőhely szerkezetéből kiinduló számítógépes (in silico) módszerek gazdag kínálatát hasznosítjuk. A következő szakaszban a farmakofórokat egyesítjük, ami a 3. ábrán bemutatott háromféle módon lehetséges. A fehérjekötő helyek ismeretében valószínúsíteni is lehet, hogy melyik kapcsolódási mód lesz optimális. Az a út a 'fúziós kapcsolás', a $b$ út szerinti az 'összeolvasztás' ('hibridképzésnek' is nevezik), amely csak akkor lehet eredményes, ha a két farmakofórnak vannak közös és nincsenek a kötődést gátló, kizáró elemei. A $c$ mód szerinti 'áthidalás' pedig különösen térben elérhető távolságban lévő kötőhelyek esetében lehet célszerû megoldás.

Fontos megjegyezni, hogy a farmakológiai vizsgálatok szerint a farmakofórokat optimálisan/közel optimálisan egyesítő molekula nagyon sokféle további kritériumnak is meg kell, hogy feleljen a gyógyszerré váláshoz; ez farmakodinámiás hatásának finomhangolásával és ADMETtulajdonságainak optimalizálásával érhető el. E szempontból a 3. ábra $a-c$ farmakofórkapcsolási lehetősége nem egyenértékú. Az a vagy a $c$ típusú kapcsolás általában kevésbé előnyös, mint a $b$ típusú, mert az előző két megoldás szignifikánsan nagyobb molekulatömeget (és lipofilitást) idéz elő, ami a gyógyszerjelölt kedvezőtlen fizikai-kémai és ADMET-tulajdonságait is okozhatja.

A multifaktoriális neurodegeneratív betegségek kezelésére és/vagy diagnosztikájára alkalmas új, több támadáspontú hatóanyagok kutatásában a farmakofórok egyesítésén alapuló stratégia különösen népszerú [14, 15, 20]; az alábbiakban két ilyen példát ismertetünk.

Az Alzheimer-kór kezelésére alkalmas, széles hatásspektrumú hatóanyagok fejlesztésében különösen a University Bologna kutatói értek el szép eredményeket. Például AChE-gátló farmakofórt egy, a patomechanizmus szempontjából releváns másik komponenssel kombinál- 


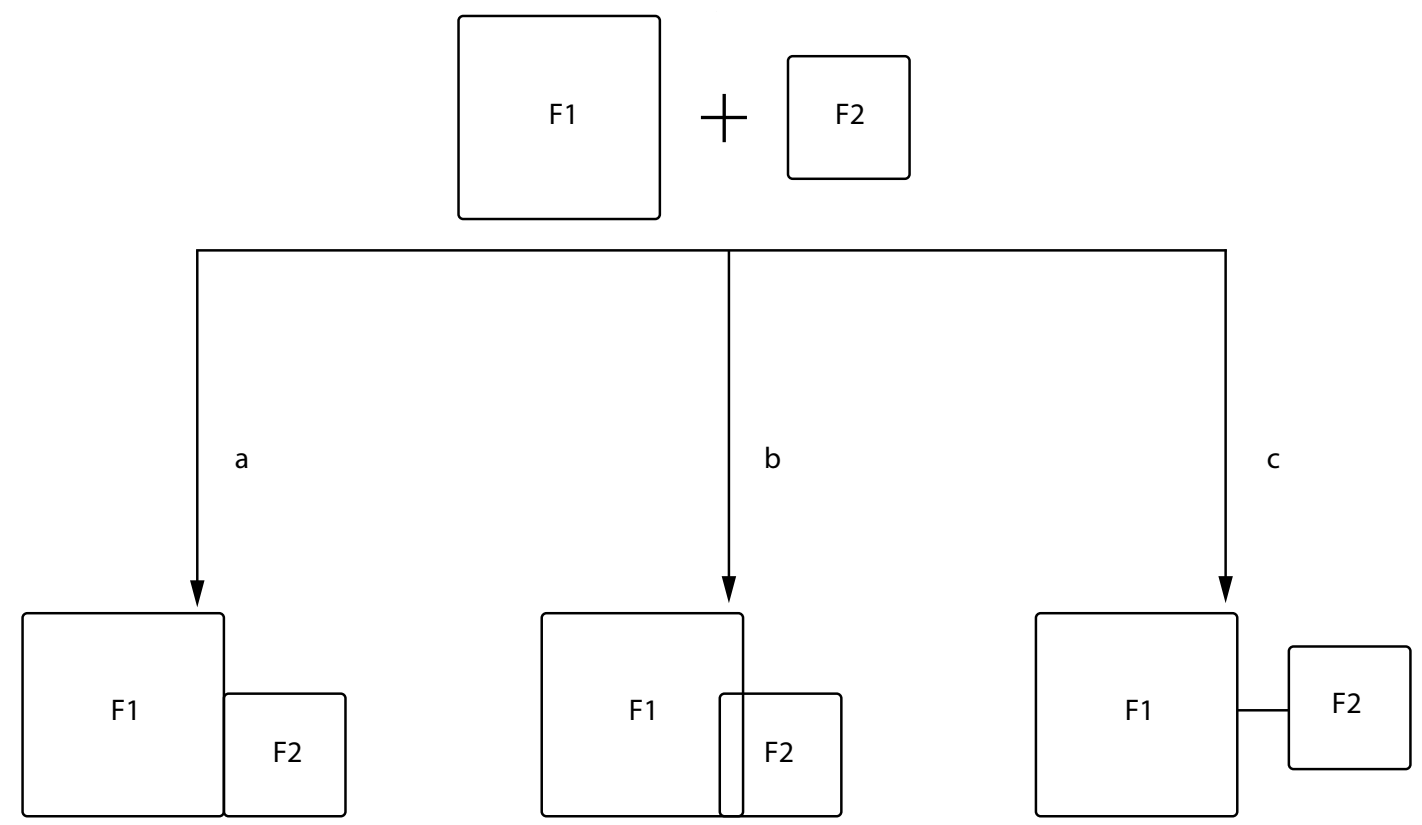

tak. Egyik érdekes vegyületük az AChE-inhibitor galantamin és az NMDA-gátló memantin összekapcsolásával előállított memagal (4. ábra), amely duális hatásának megfelelően szignifikáns neuroprotektív hatást fejt ki sejtkultúramodellben [24].

Az Alzheimer-kór kezelésére és diagnosztikájára egyaránt alkalmas teranosztikus molekulát állítottak elő a Pécsi Tudományegyetem munkatársai, együttmúködve a<smiles>COc1ccc2c3c1O[C@H]1C[C@@H](O)C=C[C@]31CCN(C)C2</smiles>

Galantamin

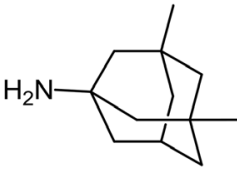

Memantin<smiles>COc1ccc2c3c1O[C@H]1C[C@@H](O)C=C[C@]31CCN(CCCCCCNC13CC4CC(C)(CC(C)(C4)C1)C3)C2</smiles>

Memagal

4. ábra

Memagal, egy kettős támadáspontú neuroprotektív hatóanyag az AChE-inhibitor galantamin és az NMDA-gátló memantin ‘áthidalás' típusú összekapcsolásával

AChE $=$ acetilkolin-észteráz $; \mathrm{NMDA}=N$-metil- $D$-aszparaginát
University of California (Davis, CA, USA) kutatóival. A HO-4160 vegyület (5. ábra) egy terápiás és egy diagnosztikai információt szolgáltató farmakofórt kombinál. A molekula policiklusos csoportjával az A $\beta$ felületén kötődik, ezáltal megakadályozza az $\mathrm{A} \beta$ polimerizációját, míg a molekula stabilis nitroxidszerkezeti része az $\mathrm{A} \beta$ által okozott oxidatív stresszt képes gátolni. Ez utóbbi molekularészlete révén a vegyület MRI-kontrasztanyagként is használható [25].

Megfelelő farmakofórok kombinálásának további célja lehet a biztonságos, mellékhatásmentes profil, amit a valamelyik hatáskomponensból származó, potenciálisan veszélyes mellékhatás gátlásával lehet elérni. Egyik saját példánkkal illusztráljuk ezt a lehetőséget. Új antiaritmiás vegyületek területén a Gyógyszerkutató Intézet és a Szegedi Tudományegyetem együttmúködésével az 198090-es években koncepcionálisan új, kettős támadáspontú antiaritmiás vegyületeket terveztünk, egyébként az elsők között a több támadáspontú hatóanyagok kutatásában [26]. Célunk az volt, hogy Ib és III. antiaritmiás osztá-

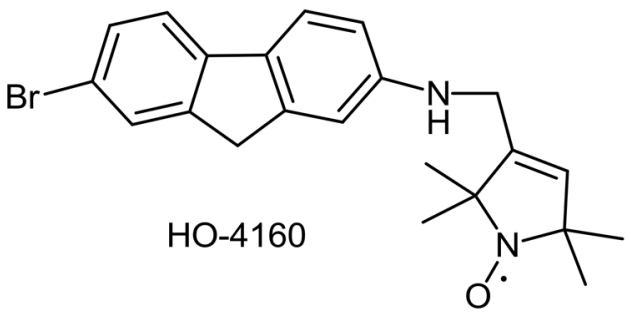

5. ábra A HO-4160, új típusú teranosztikus vegyület. A molekulának az
Alzheimer-kór kezelésére alkalmas kettős hatását a policiklusos
csoportja (gátolja a béta-amiloid fehérje polimerizációját) és a
nitroxidszerkezeti rész (antioxidáns) eredményezi; az utóbbi
révén a vegyület MRI-jelzómolekulaként is alkalmazható
MRI = mágnesesrezonancia-képalkotás 
<smiles>Cc1cccc(C)c1OCC(C)N</smiles>

Mexiletin<smiles>COS(=O)(=O)Nc1ccc(CCN(C)CCOc2ccc(NS(C)(=O)=O)cc2)cc1</smiles><smiles>[R]c1cccc([Y2])c1OCC([R])C([R])C([R8])N([R2])CC</smiles>

(I)<smiles>Cc1cccc(C)c1OCC(C)N(C)CCc1ccc(NS(C)(=O)=O)cc1</smiles>

6. ábra

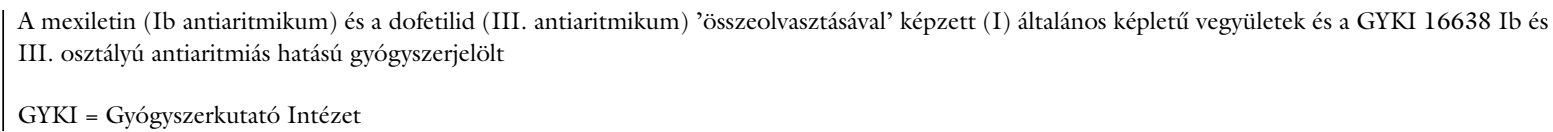

lyok szerinti hatáskomponenseket ötvözzünk egy molekulába. Így azt vártuk, hogy a molekula a két osztály előnyeit mellékhatások nélkül jeleníti meg (azáltal, hogy a III. osztály potenciálisan veszélyes mellékhatását az Ib komponens kivédi).

Az egyik projektünkben a kettős támadáspont érdekében a megfelelő farmakofórokat összeolvasztottuk. Ennek megfelelően az Ib és a III. osztály (a 6. ábrán képviselőjükként a mexiletin, illetve a dofetilid szerepel) farmakofórjainak azonosítása után a farmakofórok összeolvasztásával az (I) általános képletú vegyületcsalád számos tagját állítottuk elő. Közülük a GYKI 16638 vegyületet választottuk ki részletes preklinikai vizsgálatra, melynek várt előnyös kettős hatását és biztonságosságát in vitro és in vivo modellekben igazoltuk [27, 28].

\section{Több támadáspontú hatóanyagok több hatáskomponensü molekula azonositásával}

Gyógyszerjelöltek preklinikai vagy klinikai vizsgálatakor vagy gyógyszerek forgalmazása után a molekula több célpontot is befolyásoló képességének véletlen felismerése gyakran lehet a forrása új, több támadáspontú hatóanyag felfedezésének és fejlesztésének.

Ezt saját példánkkal illusztráljuk. A több támadáspontú antiaritmiás vegyületek fejlesztésére irányuló programunk - amelynek egyik példáját a fentiekben ismertettük - másik projektjében a kémiai kiindulópontot egy nem antiaritmikumként, hanem spazmolitikumként fejlesz- tett molekula képezte. E vegyület részletes vizsgálatakor derült ki, hogy a nátrium- és káliumion-csatornákra is van hatása. Felismerve e hatásegyüttesnek a mi számunkra való hasznosíthatóságát, majd a vegyület analógjait elóállítva, a szerkezetet a kívánt antiaritmiás profilhoz optimalizáltuk. Így jutottunk a hatásmódjában is új, több hatáskomponensű E-7229/GYKI 16306 gyógyszerjelölthöz (7. ábra) [29], amelynek komplett preklinikai fejlesztését az EGIS Gyógyszergyárban végezték el, majd ott választották ki klinikai vizsgálatra.

A gyógyszerkincs gazdag tárházát képező, természetes eredetű hatóanyagok összetett hatásmódját szintén hasznosítani lehet rokon szerkezetú molekulák tervezésére és új hatóanyagok fejlesztésére.

Több hatáskomponenst megjelenítő molekula azonosítható HTS-módszerekkel is. Az eljárásban nagyszámú (akár sok százezer) vegyületet szürnek - szekvenciáli-<smiles>COc1ccc(CCN(C)CCCNc2c(Cl)cn[nH]c2=O)cc1OC</smiles>

7. ábra A több hatáskomponensű E-7229/GYKI 16306 antiaritmiás
gyógyszerjelölt
GYKI = Gyógyszerkutató Intézet 


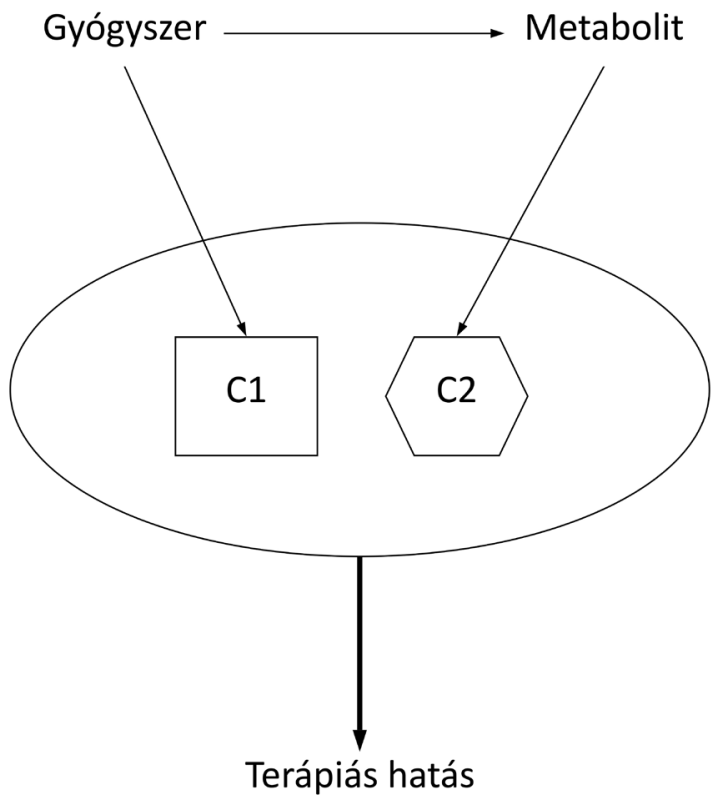

8. ábra

Több támadáspontú hatás metabolikus aktiválással (MAMUTstratégia). Az egyik hatáskomponenst maga a gyógyszermolekula ('anyavegyület'), a másikat a metabolitja szolgáltatja

MAMUT = több támadáspontú hatás metabolikus aktiválással

san - mindegyik célpont szerint, majd közülük kerül kiválasztásra a több hatáskomponenst megjelenítő, optimalizálásra alkalmas jelölt.

\section{Több támadáspontú hatóanyagok metabolikus aktiválással}

Az általunk néhány éve kidolgozott MAMUT-stratégia szerint, több támadáspontú batás metabolikus aktiválással, a két szinergikus hatáskomponens egyikét maga a gyógyszermolekula ('anyavegyület'), míg a másikat a metabolitja szolgáltatja (8. ábra) [30]. Ezt a megoldást az a felismerésünk alapozta meg, hogy több, különösen előnyös hatásspektrumú gyógyszer esetében a gyógyszernek és metabolitjának eltérő mechanizmusú, egymást erősítő hatásai egyaránt hozzájárulnak a célhatás- hoz. Ennek egyik példája a razagilin: az anyamolekula erôs irreverzibilis MAO-B-enzim-gátló hatása és 1-(R)aminoindán metabolitjának neuroprotektív hatása [31] együttesen érvényesülnek a gyógyszer Parkinson-kór kezelésére alkalmas terápiás hatásában.

Mi egy új típusú, széles spektrumú gyulladásgátló hatóanyag fejlesztését kívántuk e stratégia szerint két gyulladásgátló (SSAO-gátló + COX-gátló) hatáskomponens kombinálásával megvalósítani. Így az anyamolekulának két igényt kellett kielégítenie: egyrészt az SSAO-gátló hatás kifejtését, másrészt metabolikus átalakulással egy COX-gátló metabolit képzését. Az utóbbi megjelenítőjeként az ismert gyulladásgátló gyógyszert, az oxaprozint választottuk (9. ábra). E kívánalmak szerint, az SSAO-gátlás szerkezeti feltételeinek ismeretében született az SZV-1287 molekula. A kémiai szintézis, karakterizálás, valamint a kezdeti farmakológiai munkák a Semmelweis Egyetemen történtek [32, 33]. A részletes preklinikai vizsgálatok a Pécsi Tudományegyetemen folytatódtak, ahol a vegyület nagyítható kémiai szintézisét, teljes farmakológiai hatásspektrumát és hatásmechanizmusát is tisztázták $[34,35]$. Ennek során további innovatív felismerések születtek, így értékes hatáskomponenseket (TRPVl-és TRPAl-gátlás) is azonosítottak [36].

Jelenleg az SZV-1287 gyógyszerjelöltet neuropátiás fájdalom kezelésére [37] a Pécsi Tudományegyetem és a Toxi-Coop Zrt. (a gyógyszerbiztonsági vizsgálatok elvégzésével) együtt fejlesztik, a tervek szerint jövőre kezdődik humán klinikai vizsgálata.

\section{Merre és hogyan tovább, több támadáspontú gyógyszerkutatás?}

A gyógyszerjelöltek kiválasztásának útja és módja a gyógyszer-innováció eredményességét döntően befolyásolja. Az egy célpontú megközelítés mellett terjedt el az egy betegség - több támadáspont - egy gyógyszer koncepció. Első szakaszában néhány, izoláltan mérlegelt célpontra történt a molekulatervezés és optimalizálás. Ebből fejlődött ki a holisztikus, rendszeralapú megközelítés, amellyel az optimális gyógyszerhatás meghatározásához

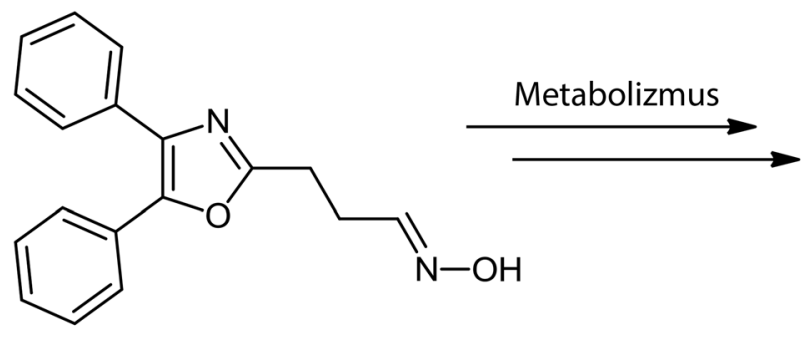

SZV-1287

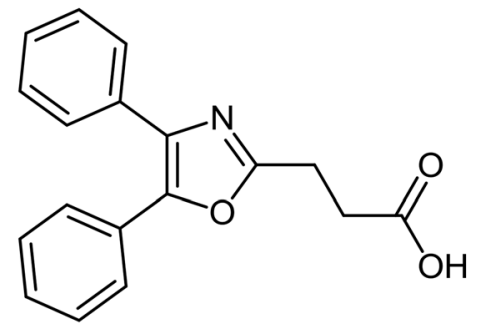

Oxaprozin

9. ábra

A MAMUT-elv szerint tervezett, több hatáskomponensű SZV-1287 gyógyszerjelölt. Az anyamolekula SSAO-gátló, metabolitja (oxaprozin) COX gátló

COX = ciklooxigenáz; MAMUT = több támadáspontú hatás metabolikus aktiválással; $\mathrm{SSAO}=$ szemikarbazid-szenzitív aminoxidáz 
a gyógyszerhatás és a betegség komplexitását is figyelembe vesszük $[18,38-40]$. Ennek továbbfejlesztéséhez a több támadáspontú megközelítést korszerű adatelemzési technikák alkalmazásával, a - rendszerbiológián túlmutató - kvantitatív rendszerfarmakológia [41] elveivel és eszközeivel célszerü összekapcsolni [42-44]. Ezzel a kiterjesztéssel a gyógyszerjelöltet a biológiai rendszer egy vagy több kapcsolati útvonalának vagy hálózatának vagy akár teljes omikai spektrumával kifejezett molekuláris fiziológiájának/patofiziológiájának a befolyásolására való alkalmassága szempontjából kvantitatíve minősíthetjük. Ez az új keret természetesen új molekulatervezési és -optimalizálási gyógyszerkémiai megoldásokat is igényel. Az egy támadáspontú vegyületekre kialakított preklinikai elvi-technológiai minősítőplatform, a maga filozófiájából eredő, túlságosan formalizált, gyakran merev szabályokhoz ragaszkodó kereteivel [45], nyilvánvalóan nem vihetô át változatlan formában a rendszerszemléletű, több támadáspontú hatóanyagok kreatív megoldásoknak is jelentős teret hagyó kutatási, fejlesztési struktúrájába. Bizonyos elemeik, például számítógépes tervezési, optimalizálási módszerek, kiegészítve és megújítva új adatanalitikai, köztük mesterségesintelligencia-módszerekkel [46-48], hatékonyak lehetnek a tartalmi jellegében megújuló, több támadáspontú, új elnevezéssel rendszerfarmakológiai hatóanyagok [49] kutatásában is. Ez az elvi-gyakorlati platform alkalmazható lesz új típusú diagnosztikumok és teranosztikumok innovációjára is, olyan új jelző- és teranosztikus molekulák fejlesztésére, melyek két/több diagnosztikai módszert (például PET-MRI) szolgálnak, illetve terápiás hatás és diagnosztikai képesség megjelenítésére egyaránt képesek.

\section{Következtetés}

Megállapítható, hogy a több támadáspontú, új elnevezéssel rendszerfarmakológiai gyógyszer koncepció [49] új formájában és megvalósítási környezetével, a precíziós medicina [50] igényeinek kielégítésével új típusú gyógyszerek, kombinációs készítmények [51], sőt új gyógyszer-repozíciós jelöltek $[23,52,53]$ fejlesztésére is alkalmas, és így a gyógyszer-innováció eredményes jövőjének is egyik meghatározó tényezóje lehet.

Anyagi támogatás: A közlemény megírása anyagi támogatásban nem részesült.

A szerző a kézirat végleges változatát elolvasta és jóváhagyta.

Érdekeltség: A szerzőnek nincsenek érdekeltségei.

\section{Köszönetnyilvánítás}

Ez alkalommal is tisztelettel és köszönettel gondolok néhai Kasztreiner Endrére, akinek vezetésével a Gyógyszerkutató Intézetben az 1980-as években kezdtünk el foglalkozni a több támadáspontú hatóanyagok tervezésével és szintézisével. Külön köszönöm Varró Andrásnak (SZTE) és Papp Gyulának (SZTE) az antiaritmiás vegyületek, Gyires Klárának (SE), Helyes Zsuzsannának (PTE), nébai Magyar Kálmánnak (SE), Szökö Évának (SE) az SSAO-gátló vegyületek kutatásában, Christina Chainak (Natl. Univ. Singapore) és Kálai Tamásnak a gyógyszerkémiai munkákban a megtisztelő együttmúködést és a tanulságos, baráti diszkussziókat. Köszönet illeti a Szerves Vegytani Intézet (SE) közösségét, a PTE mindazon munkatársát, akik az SSAO-gátló vegyületek, különösen az SZV-1287 gyógyszerjelölt kémiai, farmakológiai és gyógyszer-technológiai munkáiban részt vettek, valamint Hirka Gábort (Toxi-Coop Zrt.) és munkatársait a gyógyszer-biztonságossági vizsgálatokért; továbbá a hivatkozott saját közlemények és szabadalmak valamennyi társszerzőjét. Gál Péternek, Szócska Miklósnak az Egészségügyi Közszolgálati Kar (SE) korábbi, illetve jelenlegi dékánjának, Kuthy Antal vezérigazgatónak és helyettesének, Kuthy Domokosnak (E-Group) támogató együttmúködésükért és bizalmukért különösen hálás vagyok. A kézirat formai szerkesztésében nyújtott készséges segítségét Berki Juliának köszönöm. A közlemény megírására az 'Új, több támadáspontú innovatív fájdalomcsillapító fejlesztése: hatástani, preklinikai és humán fázis I. vizsgálatok' címú GINOP-2.2.115-2016-00020. és a 'Hálózatos analitikai és adathasznosítási lehetőségek az egészségügyben' címü, GINOP-2.2.1-15-2017-00067. számú pályázati projektek keretében került sor.

\section{Irodalom}

[1] Mullard A. 2018 FDA drug approvals. Nat Rev Drug Discov. 2019; 18: 85-89.

[2] DiMasi JA, Grabowski HG, Hansen RW. Innovation in the pharmaceutical industry: new estimates of $R \& D$ costs. J Health Econ. 2016; 47: 20-33.

[3] Wong CH, Siah KW, Lo AW. Estimation of clinical trial success rates and related parameters. Biostatistics 2019; 20: 273-286. [Correction: Biostatistics 2019; 20: 366.]

[4] Beadeker M, Ringel M, Schulze U. 2018 FDA approvals hit all time high - but average value slips again. Nat Rev Drug Discov. 2019; 18: 90.

[5] Mignani S, Huber S, Tomás H, et al. Why and how have drug discovery strategies in pharma changed? What are the new mindsets? Drug Discov Today 2016; 21: 239-249.

[6] Scannell JW, Bosley J. When quality beats quantity: decision theory, drug discovery, and the reproducibility crisis. PLoS ONE 2016; 11: e0147215.

[7] Lin HH, Zhang LL, Yan R, et al. Analysis of drug-target interactions: a study on FDA-approved new molecular entities between 2000 to 2015. Sci Rep. 2017; 7: 12230.

[8] Ramsay RR, Popovic-Nikolic MR, Nikolic K, et al. A perspective on multi-target drug discovery and design for complex diseases. Clin Transl Med. 2018; 7: 3.

[9] Baldwin JJ, Lumma WC Jr, Lundell GF, et al. Symbiotic approach to drug design: antihypertensive beta-adrenergic blocking agents. J Med Chem. 1979; 22: 1284-1290.

[10] Clifton JE, Collins I, Hallett P, et al. Arylethanolamines derived from salicylamide with alpha- and beta-adrenoceptor blocking activities. Preparation of labetalol, its enantiomers, and related salicylamides. J Med Chem. 1982; 25: 670-679.

[11] Wong DT, Robertson DW, Bymaster FP, et al. LY227942, an inhibitor of serotonin and norepinephrine uptake: biochemical pharmacology of a potential antidepressant drug. Life Sci. 1988; 43: 2049-2057.

[12] Nelson MH, Dolder CR. Lapatinib: a novel dual tyrosine kinase inhibitor with activity in solid tumors. Ann Pharmacother. 2006; 40: 261-269.

[13] Kiss B, Horváth A, Némethy Zs, et al. Cariprazine (RGH-188), a dopamine $\mathrm{D} 3$ receptor-preferring, D3/D2 dopamine receptor antagonist-partial agonist antipsychotic candidate: in vitro and neurochemical profile. J Pharmacol Exp Ther. 2010; 333: 328340 . 
[14] Morphy R, Rankovic Z. Designed multiple ligands. An emerging drug discovery paradigm. J Med Chem. 2005; 48: 6523-6543.

[15] Bolognesi ML, Banzi R, Bartolini M, et al. Novel class of quinone-bearing polyamines as multi-target-directed ligands to combat Alzheimer's disease. J Med Chem. 2007; 50: 4882-4897.

[16] Proschak E, Stark H, Merk D. Polypharmacology by design: a medicinal chemist's perspective on multitargeting compounds. J Med Chem. 2019; 62: 420-444.

[17] Meunier B. Hybrid molecules with a dual mode of action: dream or reality? Acc Chem Res. 2008; 41: 69-77.

[18] Peters JU. Polypharmacology - foe or friend? J Med Chem. 2013; 56: 8955-8971.

[19] Kerru N, Singh P, Koorbanally N, et al. Recent advances (20152016) in anticancer hybrids. Eur J Med Chem. 2017; 142: 179212.

[20] León R, Garcia AG, Marco-Contelles J. Recent advances in the multitarget-directed ligands approach for the treatment of Alzheimer's disease. Med Res Rev. 2013; 33: 139-189.

[21] Raghavendra NM, Pingili D, Kadasi S, et al. Dual or multi-targeting inhibitors: the next generation anticancer agents. Eur J Med Chem. 2018; 143: 1277-1300.

[22] Saenz-Méndez P, Eriksson LA. Exploring polypharmacology in drug design. Methods Mol Biol. 2018; 1824: 229-243.

[23] Mei Y, Yang B. Rational application of drug promiscuity in medicinal chemistry. Future Med Chem. 2018; 10: 1835-1851.

[24] Simoni E, Daniele S, Bottegoni G, et al. Combining galantamine and memantine in multitargeted, new chemical entities potentially useful in Alzheimer's disease. J Med Chem. 2012; 55: 9708-9721.

[25] Hilt S, Tang T, Walton JH, et al. Metal-free method for producing MRI contrast at amyloid-beta. J Alzheimers Dis. 2017; 55: 1667-1681.

[26] Mátyus P, Varró A, Papp Gy, et al. Antiarrhythmic agents: current status and perspectives. Med Res Rev. 1997; 17: 427-451.

[27] Baczkó I, El-Reyani NE, Farkas A, et al. Antiarrhythmic and electrophysiological effects of GYKI-16638, a novel N(phenoxyalkyl)- $\mathrm{N}$-phenylalkylamine, in rabbits. Eur J Pharmacol. 2000; 404: 181-190.

[28] Opincariu M, Varró A, Iost N, et al. The cellular electrophysiologic effect of a new amiodarone like antiarrhythmic drug GYKI 16638 in undiseased human ventricular muscle: comparison with sotalol and mexiletine. Curr Med Chem. 2002; 9: 41-46.

[29] Mátyus P. Cardiovascular system research at the Institute of Drug Research. [Kardiovaszkuláris hatóanyagok kutatása a Gyógyszerkutató Intézetben.] Acta Pharm Hung. 2001; 71: 67-72. [Hungarian]

[30] Mátyus P, Chai CL. Metabolism-activated multitargeting (MAMUT): an innovative multitargeting approach to drug design and development. Chem Med Chem. 2016; 11: 11971198.

[31] Bar-Am O, Weinreb O, Amit T, et al. The neuroprotective mechanism of $1-(\mathrm{R})$-aminoindan, the major metabolite of the antiparkinsonian drug rasagiline. J Neurochem. 2010; 112: 11311137.

[32] Mátyus P, Magyar K, Pihlavisto M, et al. WO/2010/029379 Compounds for inhibiting semicarbazide-sensitive amine oxidase $(\mathrm{SSAO}) /$ vascular adhesion protein-1 (VAP-1) and uses thereof for treatment and prevention of diseases. 2010; PCT international application: WO/2010/029379

[33] Tábi T, Szökő É, Mérey A, et al. Study on SSAO enzyme activity and anti-inflammatory effect of SSAO inhibitors in animal model of inflammation. J Neural Transm. 2013; 120: 963-967.

[34] Helyes Z, Mátyus P, et al. Semicarbazide-sensitive amine-oxidase inhibitors, as analgesics in traumatic neuropathy and neurogenic inflammation. 2014; Hungarian and USA PCT: P1400205.

[35] Horváth Á, Menghis A, Botz B, et al. Analgesic and anti-inflam matory effects of the novel semicarbazide-sensitive amine-oxi- dase inhibitor SzV-1287 in chronic arthritis models of the mouse. Sci Rep. 2017; 7: 39863.

[36] Payrits M, Sághy É, Mátyus P, et al. A novel 3-(4,5-diphenyl-1,3oxazol-2-yl)propanal oxime compound is a potent transient receptor potential ankyrin 1 and vanilloid 1 (TRPAl and Vl) receptor antagonist. Neuroscience 2016; 324: 151-162.

[37] Horváth Á, Tékus V, Bencze N, et al. Analgesic effects of the novel semicarbazide-sensitive amine oxidase inhibitor $\mathrm{SzV}-1287$ in mouse pain models with neuropathic mechanisms: involvement of transient receptor potential vanilloid 1 and ankyrin 1 receptors. Pharmacol Res. 2018; 131: 231-243.

[38] Csermely P, Ágoston V, Pongor S. The efficiency of multi-target drugs: the network approach might help drug design. Trends Pharmacol Sci. 2005; 26: 178-182.

[39] Moya-García A, Adeyelu T, Kruger FA, et al. Structural and functional view of polypharmacology. Sci Rep. 2017; 7: 10102.

[40] Talevi, A. Multiple-target pharmacology: possibilities and limitations of the "skeleton key approach" from a medicinal chemist perspective. Front Pharmacol. 2015; 6: 205.

[41] Helmlinger G, Sokolov V, Peskov K. Quantitative systems pharmacology: an exemplar model-building workflow with applications in cardiovascular, metabolic, and oncology drug development. CPT Pharmacometrics Syst Pharmacol. 2019; 8: 380-395.

[42] van Hasselt JG, van der Graaf PH. Towards integrative systems pharmacology models in oncology drug development. Drug Discov Today Technol. 2015; 15: 1-8.

[43] Geerts H, Roberts P, Spiros A, et al. Assessing the synergy between cholinomimetics and memantine as augmentation therapy in cognitive impairment in schizophrenia. A virtual human patient trial using quantitative systems pharmacology. Front Pharmacol. 2015; 6: 198 .

[44] Thiel C, Smit I, Baier V, et al. Using quantitative systems pharmacology to evaluate the drug efficacy of COX-2 and 5-LOX inhibitors in therapeutic situations. NPJ Syst Biol Appl. 2018; 4: 28.

[45] Chai CL, Mátyus P. One size does not fit all: challenging some dogmas and taboos in drug discovery. Future Med Chem. 2016; 8: 29-38.

[46] Rastelli G, Pinzi L. Computational polypharmacology comes of age. Front Pharmacol. 2015; 6: 157.

[47] Sellwood MA, Ahmed M, Segler MH, et al. Artificial intelligence in drug discovery. Future Med Chem. 2018; 10: 2025-2028.

[48] Vamathevan J, Clark D, Czodrowsky P, et al. Applications of machine learning in drug discovery and development. Nat Rev Drug Discov. 2019; 18: 463-477.

[49] Pritchard KA Jr, Martin DP, Naylor S. Systems pharmacology: when multi-targeting is advantageous. Drug Discov World 2018/19 Winter issue. Available from: https://www.ddw-online.com/therapeutics/p322783-systems-pharmacology:-whenmulti-targeting-is-advantageous.html [accessed: December 14, 2019].

[50] Lim H, He D, Qiu Y, et al. Rational discovery of dual-indication multi-target PDE/kinase inhibitor for precision anti-cancer therapy using structural systems pharmacology. PLOS Comput Biol. 2019; 15: e1006619.

[51] van Hasselt JG, Iyengar R. Systems pharmacology: defining the interactions of drug combinations. Annu Rev Pharmacol Toxicol. 2019; 59: 21-40.

[52] Cheng F. In silico oncology drug repositioning and polypharmacology. Methods Mol Biol. 2019; 1878: 243-261.

[53] Khalid Z, Sezerman OU. Computational drug repurposing to predict approved and novel drug-disease association. J Mol Graph Model. 2018; 85: 91-96.

(Mátyus Péter dr., Budapest, Ferenc tér 15., 1094 e-mail: peter.maty@gmail.com)

A cikk a Creative Commons Attribution 4.0 International License (https://creativecommons.org/licenses/by/4.0/) feltételei szerint publikált Open Access közlemény. (SID_1) 